\title{
Structural Modifications of the Small Intestine of the African Giant Rat (Cricetomys gambianus, Waterhouse): Implications for Dietary demands and Improved Domestication
}

\author{
Samuel Gbadebo Olukole ${ }^{1, a, *}$, Olatunji-Akioye Adenike Olusola ${ }^{2, b}$, Oluwaseyi Oyeniyi Owolabi ${ }^{1, c}$, \\ Bankole Olusiji Oke ${ }^{1, d}$ \\ ${ }^{I}$ Department of Veterinary Anatomy, Faculty of Veterinary Medicine University of Ibadan, Nigeria. \\ ${ }^{2}$ Department of Veterinary Surgery and Radiology Faculty of Veterinary Medicine University of Ibadan, Nigeria \\ *Corresponding author \\ A R T I C L E I N F O A B S T R A C T \\ Research Article \\ The African giant rat (Cricetomys gambianus, Waterhouse) is a wild rodent in sub-Saharan Africa \\ widely hunted as popular meat delicacy. Domestication of this rat has been poor, probably due to \\ nutrition among other factors. Developmental studies of the duodenum, jejunum and ileum as well \\ as investigations of diet-based structural modifications of the small intestine were carried out in the \\ Received : $13 / 02 / 2020$ \\ Accepted : 22/05/2020 \\ rats using neonates, juveniles and adults with the aim of providing useful research information \\ which could lead to improved domestication. The mean body weights of the animals were \\ $39.67 \pm 1.45 \mathrm{~g}, 225.00 \pm 25.00 \mathrm{~g}$ and $742.90 \pm 62.13 \mathrm{~g}$, respectively for the neonate, juvenile and adult \\ rats. Significant differences were also observed in the villus height, villus width and crypt depth \\ between the neonates and juveniles, unlike between juvenile and adult rats. These changes in \\ intestinal morphology between the neonate and juvenile rats could be a measure of the neonates' \\ adaptation to shifts from digestion of maternal milk to the consumption of solid and semisolid \\ forages. Respectively for neonates, juvenile and adult rats, $188 \%, 228 \%$ and $30 \%$ increases in villus \\ height for the duodenum, jejunum and ileum respectively, were observed. This is suggestive of \\ larger surface area of the small intestine for digestion and absorption. This study elucidates the \\ structural modifications of the small intestine which can be applied to dietary modifications in \\ response to age in an effort to achieve a more successful domestication of the animal.

Keywords:
Adult
Juvenile
Morphology
Neonate
Intestine

\section{Introduction}

The African giant rat (Cricetomys gambianus, Waterhouse) is a wild rodent widely spread in sub-Saharan Africa (Moutairu et al., 1996; Olude et al., 2017). It belongs to the order rodentia and is quite common in Nigeria being more dominant in the Savannah areas of the country (Ajayi, 1974). The African giant rat (AGR) has been reported to have attained an enormous weight of about $1.40 \mathrm{~kg}$ with a total length of $83 \mathrm{~cm}$ from the tip of the nose to the tip of the tail (Happlod, 1987). The animal is a popular meat delicacy among the local people who hunt it for food. Unlike this rodent, the domestication of the African greater cane rat, a closely related rodent (also widely hunted for its acceptance as meat delicacy), has been successful with age-related documentations available (Monadjem et al., 2015; Omirinde et al., 2019).

There are two important periods in the gastrointestinal adaptation of the newborn mammal to enteral nutrition: birth and weaning (Weaver and Carrick, 1989). Those changes which occur perinatally have been well studied, particularly in rodents (Weaver, 1986; Henning, 1987). Changes in the morphology of the intestines are largely concerned with the transition from intrauterine parenteral nutrition to extrauterine enteral nutrition. Weaning, the period of transition from milk to solid feeding, has also been the subject of studies in the rat and mouse but little is known of the process in several other rodent species, especially the AGR (Van den Bogert et al., 2011; Hugeholtz and de Vos, 2018).

Morphometric studies in a number of rodents indigenous to Africa had been reported by a few authors: the biometrical observations on the testis and epididymis of the domesticated African greater cane rat (Olukole et al., 2009); morphometric analysis of the kidneys of the domesticated African greater cane rat (Olukole, 2009); age-related changes in brain morphology (Olude et al., 2017) among others. Recent studies on the African giant rat had mainly focused on hematology (Durotoye and Oke, 1990) and reproduction (Oke et al., 1988, 1989 and Oke and Aire, 1996). Recently, Ellis et al. (2017) demonstrated the reproducibility of African giant pouched rats detecting Mycobacterium tuberculosis. 
Little is known about the developmental anatomy of the small intestine of the African giant rat. This study was therefore designed to investigate the gross and histological aspects of the developmental morphology of the small intestine of the African giant rat with the aim of providing useful information which could lead to an improved domestication of the animal with respect to structural modifications in neonate, juvenile and adult animals.

\section{Materials and Methods}

\section{Experimental Animals}

Fifteen African Giant rats of three developmental stages (neonate, juvenile and adult) which were captured directly from the wild were used for the study. The protocol used in the study was approved by the University of Ibadan Animal Care and Use Research Ethics Committee Review (UI-ACUREC) UI-ACUREC/18/0120.

Five rats per developmental stages were identified as earlier reported by Olude et al. (2017) The rats were kept at the African Giant Rat Unit of the Animal House, Faculty of Veterinary Medicine, University of Ibadan, Nigeria, where they were fed with commercial pelletized rat feed (Ladokun Feeds ${ }^{\circledR}$ ) ad libitum and were acclimatized for 7 days prior to slaughtering. They were examined and found to be physically healthy, anaesthetized using chloroform and weighed with the aid of a Microvar ${ }^{\circledR}$ weighing balance before being slaughtered by cervical decapitation. Following this, each rat was placed on a dissection board in dorsal recumbency while a shallow medioventral incision was made from the xiphoid cartilage to a point cranial to the anus in order to expose the abdominal and pelvic cavities. The entire gastro-intestinal tract was then carefully harvested. The anatomical orientations of the duodenum, jejunum and the ileum were then carefully identified and separated out.

The gross morphometric parameters were investigated using metric tape: the Crown- Rump length (CRL) as well as the lengths and widths of the intestinal sections. The weight of each segment of the small intestine was obtained with the aid of a digital weighing balance while their volume was determined by water displacement method using a calibrated measuring cylinder.

Samples were taken from the duodenum, jejunum and ileum and fixed in buffered neutral formaldehyde. These tissues were later processed for histological examinations. Sections of $5 \mu \mathrm{m}$ thick were stained with Hematoxylin and Eosin. For each of the three developmental stages, ten measurements were made per section using a calibrated eyepiece micrometer (Graticules Ltd. Toubridge Kent). The histological parameters measured for the three segments of the small intestines were villus height, crypt depth, epithelial thickness, villus width. Also measured were the widths of submucosa, lamina propria, lamina muscularis, serosa and the thickness of the muscularis mucosa.

\section{Statistical Analysis}

All data were expressed as means and standard error of means and were subjected to Analysis of Variance (ANOVA) using the Graphpad Prism version 4.00 for Windows $\left(\right.$ Graphpad $\left.^{\circledR}\right)$ Significance was reported at $\mathrm{P}<0.05$.

\section{Results}

The mean weights for the animals used in this study were $39.67 \pm 1.45 \mathrm{~g}, 225.0 \pm 25 \mathrm{~g}$ and $742.9 \pm 62.13 \mathrm{~g}$, respectively for the neonate, juvenile and adult rats. The crown-rump lengths of the rats showed significance differences $(\mathrm{P}<0.05)$ across the three developmental stages (Table 1). There was a positive correlation $(\mathrm{r}=0.60,0.73$ and 0.75 ) between the crown- rump length and the weight of the animals in each of the three developmental stages. The length of the entire small intestine unlike its weight and volume showed significant differences $(\mathrm{P}<0.05)$ across the three developmental stages of the rats (Table 1).

Table 1. Comparison of means and SEM of gross body and intestinal parameters in the different developmental stages in the African giant rat (Cricetomys gambianus, Waterhouse).

\begin{tabular}{|c|c|c|c|}
\hline Parameters & Neonates & Juveniles & Adults \\
\hline $\mathrm{WtA}(\mathrm{g})$ & $39.67 \pm 1.45$ & $225.0 \pm 25$ & $742.9 \pm 62.13$ \\
\hline CRL (cm) & $11.5 \pm 0.44^{\mathrm{a}}$ & $17.0 \pm 1.5^{\mathrm{b}}$ & $25.33 \pm 0.78^{c}$ \\
\hline VSI $\left(\mathrm{cm}^{3}\right)$ & $7.03 \pm 0.15^{\mathrm{a}}$ & $6.5 \pm 0.0^{\mathrm{a}}$ & $11.21 \pm 0.86^{b}$ \\
\hline $\operatorname{VOD}\left(\mathrm{cm}^{3}\right)$ & $1.90 \pm 0.06^{\mathrm{a}}$ & $2.75 \pm 0.25^{\mathrm{a}}$ & $4.43 \pm 0.30^{b}$ \\
\hline $\mathrm{LOD}(\mathrm{cm})$ & $4.700 \pm 0.27^{\mathrm{a}}$ & $12.75 \pm 2.75^{b}$ & $17.21 \pm 1.14^{\mathrm{c}}$ \\
\hline $\mathrm{WOD}(\mathrm{cm})$ & $0.52 \pm 0.04$ & $1.15 \pm 0.05$ & $1.00 \pm 0.02$ \\
\hline $\mathrm{WtD}(\mathrm{g})$ & $1.67 \pm 0.01^{\mathrm{a}}$ & $2.85 \pm 0.25^{\mathrm{a}}$ & $3.96 \pm 0.34^{\mathrm{a}}$ \\
\hline $\operatorname{VOJ}\left(\mathrm{cm}^{3}\right)$ & $3.10 \pm 0.06$ & $2.75 \pm 0.25$ & $3.36 \pm 0.52$ \\
\hline $\operatorname{LOJ}(\mathrm{cm})$ & $11.60 \pm 0.35^{\mathrm{a}}$ & $27.85 \pm 1.55^{\mathrm{b}}$ & $33.71 \pm 4.76^{b}$ \\
\hline $\mathrm{WOJ}(\mathrm{cm})$ & $0.40 \pm 0.06$ & $0.65 \pm 0.05$ & $0.61 \pm 0.06$ \\
\hline $\mathrm{WtJ}(\mathrm{g})$ & $1.81 \pm 0.02^{\mathrm{a}}$ & $3.80 \pm 0.40^{\mathrm{b}}$ & $7.79 \pm 1.0^{\mathrm{c}}$ \\
\hline $\operatorname{VOI}\left(\mathrm{cm}^{3}\right)$ & $2.03 \pm 0.09$ & $1.0 \pm 0.0$ & $3.29 \pm 0.29$ \\
\hline $\mathrm{LOI}(\mathrm{cm})$ & $13.40 \pm 1.51^{\mathrm{a}}$ & $36.70 \pm 0.70^{\mathrm{b}}$ & $45.84 \pm 6.39^{c}$ \\
\hline WOI(cm) & $0.43 \pm 0.03$ & $0.6 \pm 0.1$ & $0.71 \pm 0.05$ \\
\hline $\mathrm{WtI}(\mathrm{g})$ & $1.77 \pm 0.02$ & $3.35 \pm 0.25$ & $10.01+1.86$ \\
\hline $\operatorname{LSI}(\mathrm{cm})$ & $30.03 \pm 2.00^{\mathrm{a}}$ & $77.3 \pm 3.60^{\mathrm{b}}$ & $96.34+3.16^{c}$ \\
\hline WSI $(\mathrm{cm})$ & $0.53 \pm 0.03$ & $1.15 \pm 0.05$ & $0.97+0.04$ \\
\hline $\mathrm{WtSI}(\mathrm{g})$ & $5.33 \pm 0.03^{\mathrm{a}}$ & $10.0 \pm 0.40^{\mathrm{b}}$ & $21.33+2.31^{\mathrm{c}}$ \\
\hline
\end{tabular}

WtA: weight of animal, CRL: crown- rump length, VSI: volume of small intestine, VOD: volume of duodenum, LOD: length of duodenum, WOD: width of duodenum, WtD: weight of duodenum, VOJ: volume of jejunum, LOJ: length of jejunum, WOJ: width of jejunum, WtJ: weight of jejunum, VOI: volume of ileum, LOI: length of ileum, WOI: width of ileum, WtI: weight of ileum, LSI: length of small intestine, WSI: width of small intestine, WtSI: weight of small intestine, Means with different superscripts within rows are statistically significant $(\mathrm{P}<0.05)$. 

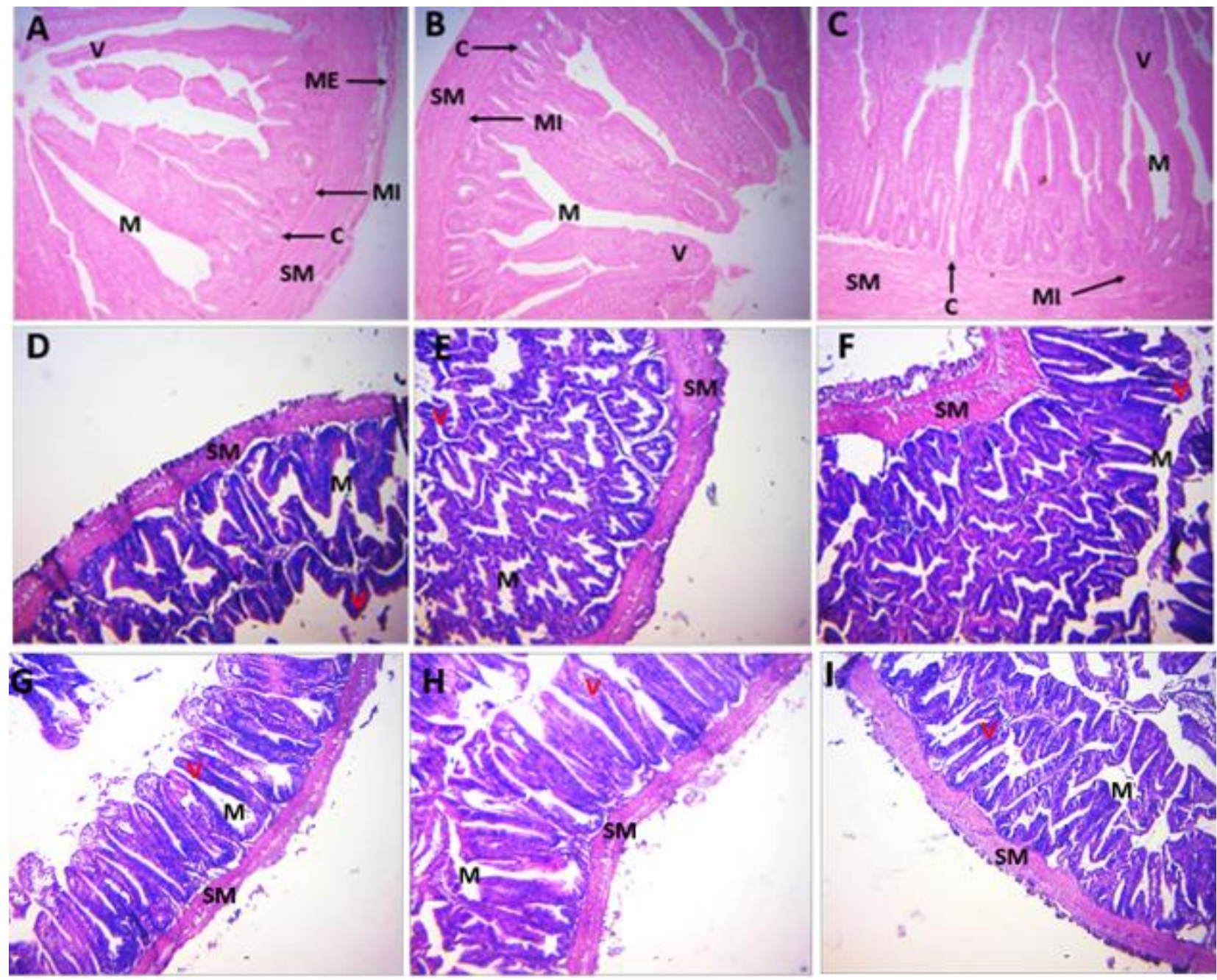

Figure 1. Light Micrograph of the small intestines of the African giant rat $(\mathrm{H} \& \mathrm{E}, \times 100)$.

Duodenum of neonate (A), Juvenile (B) and Adult (C) rats showing crypt (C), mucosa (M), submucosa (SM), muscularis externa (ME), muscularis interna (MI), villus (V). Jejunum of neonate (D), Juvenile (E) and Adult (F) rats showing mucosa (M), submucosa (SM), villus (V). Ileum of neonate (G), Juvenile (H) and Adult (I) rats showing mucosa (M), submucosa (SM), villus (V).

Table 2. Comparative histomorphometry of the duodenum at different developmental stages in the African giant rat (Cricetomys gambianus, Waterhouse).

\begin{tabular}{l|ccc}
\hline \multicolumn{1}{c|}{ Parameters } & Neonates & Juveniles & Adults \\
\hline Villus Height $(\mu \mathrm{m})$ & $183 \pm 0.011^{\mathrm{a}}$ & $527 \pm 0.05^{\mathrm{b}}$ & $529 \pm 0.05^{\mathrm{b}}$ \\
Villus Width $(\mu \mathrm{m})$ & $60.0 \pm 0.004^{\mathrm{a}}$ & $138 \pm 0.01^{\mathrm{b}}$ & $151 \pm 0.16^{\mathrm{b}}$ \\
Crypt Depth $(\mu \mathrm{m})$ & $26.0 \pm 0.003^{\mathrm{a}}$ & $50.0 \pm 0.01^{\mathrm{b}}$ & $81.0 \pm 0.01^{\mathrm{b}}$ \\
Epithelial Height $(\mu \mathrm{m})$ & $10.0 \pm 0.001^{\mathrm{a}}$ & $32.0 \pm 0.00^{\mathrm{b}}$ & $62.0 \pm 0.03^{\mathrm{c}}$ \\
Lamina proprial Width $(\mu \mathrm{m})$ & $43.0 \pm 0.003$ & $70.0 \pm 0.01$ & $87.0 \pm 0.02$ \\
Submucosal width $(\mu \mathrm{m})$ & $48.0 \pm 0.004^{\mathrm{a}}$ & $117 \pm 0.02^{\mathrm{b}}$ & $80.7 \pm 0.04$ \\
Muscularis mucosal width $(\mu \mathrm{m})$ & $209 \pm 0.009^{\mathrm{a}}$ & $577 \pm 0.05^{\mathrm{b}}$ & $610 \pm 0.05^{\mathrm{b}}$ \\
Lamina muscularis width $(\mu \mathrm{m})$ & $51.0 \pm 0.004^{\mathrm{a}}$ & $128 \pm 0.01^{\mathrm{b}}$ & $127 \pm 0.05^{\mathrm{b}}$ \\
Serosal width $(\mu \mathrm{m})$ & $16.0 \pm 0.02$ & $18.0 \pm 0.00$ & $19.0 \pm 0.01$ \\
\hline
\end{tabular}

Means with different superscripts within rows are statistically significant $(\mathrm{P}<0.05)$

The histological features of the small intestine of the African giant rat show a submucosa bounded by a thin layer of muscle, the muscularis externa (Figure 1). The submucosal surface from without inward is followed by the mucosa which bears the villus and then the lumen. The histological features of the duodenum, jejunum and ileum are given in Figure 1A-I. For the duodenum, jejunum and ileum, villus height and width, lamina propria width, submucosal width, muscularis mucosal width and lamina muscularis width all showed significant differences $(\mathrm{P}<0.05)$ between the neonates and juveniles while these parameters showed no significant differences $(\mathrm{P}<0.05)$ between the juvenile and adult rats (Tables 2-4). However, the duodenal epithelial height and crypt depth increased significantly across the three developmental stages of the rats (Table 2). In the jejunum and ileum, there were significant differences $(\mathrm{P}<0.05)$ in epithelial height and crypt depth between the neonates and juveniles (Tables 3 and 4). However, in the duodenum, jejunum and ileum, serosal width showed no significant difference $(\mathrm{P}<0.05)$ across the three developmental stages of the rat (Tables 2-4). 
Table 3. Comparative histomorphometry of the jejunum at different developmental stages in the African giant rat (Cricetomys gambianus, Waterhouse).

\begin{tabular}{l|ccc}
\hline \multicolumn{1}{c|}{ Parameters } & Neonates & Juveniles & Adults \\
\hline Villus Height $(\mu \mathrm{m})$ & $109 \pm 0.01^{\mathrm{a}}$ & $357 \pm 0.03^{\mathrm{b}}$ & $373 \pm 0.03^{\mathrm{b}}$ \\
Villus Width $(\mu \mathrm{m})$ & $39.0 \pm 0.00^{\mathrm{a}}$ & $114 \pm 0.01^{\mathrm{b}}$ & $104 \pm 0.00^{\mathrm{b}}$ \\
Crypt Depth $(\mu \mathrm{m})$ & $14.0 \pm 0.00^{\mathrm{a}}$ & $49.0 \pm 0.01^{\mathrm{b}}$ & $42.0 \pm 0.00^{\mathrm{b}}$ \\
Epithelial Height $(\mu \mathrm{m})$ & $16.0 \pm 0.02$ & $24.0 \pm 0.00$ & $22.0 \pm 0.00$ \\
Lamina proprial Width $(\mu \mathrm{m})$ & $25.0 \pm 0.01$ & $66.0 \pm 0.02$ & $57.0 \pm 0.00$ \\
Submucosal width $(\mu \mathrm{m})$ & $33.0 \pm 0.00^{\mathrm{a}}$ & $73.0 \pm 0.01^{\mathrm{b}}$ & $91.7 \pm 0.00^{\mathrm{b}}$ \\
Muscularis mucosa width $(\mu \mathrm{m})$ & $53.0 \pm 0.00^{\mathrm{a}}$ & $163 \pm 0.01^{\mathrm{b}}$ & $176 \pm 0.00^{\mathrm{b}}$ \\
Lamina muscularis width $(\mu \mathrm{m})$ & $40.3 \pm 0.00$ & $51.3 \pm 0.00$ & $77.0 \pm 0.00$ \\
Serosal width $(\mu \mathrm{m})$ & $11.0 \pm 0.00$ & $11.0 \pm 0.00$ & $11.0 \pm 0.00$ \\
\hline
\end{tabular}

Means with different superscripts within rows are statistically significant $(\mathrm{P}<0.05)$

Table 4. Comparative histomorphometry of the ileum at different developmental stages in the African giant rat (Cricetomys gambianus, Waterhouse).

\begin{tabular}{|c|c|c|c|}
\hline Parameters & Neonates & Juveniles & Adults \\
\hline Villus Height $(\mu \mathrm{m})$ & $205 \pm 0.02^{\mathrm{a}}$ & $267 \pm 0.03^{\mathrm{b}}$ & $267 \pm 0.04^{b}$ \\
\hline Villus Width $(\mu \mathrm{m})$ & $291 \pm 0.25^{\mathrm{a}}$ & $89.0 \pm 0.01^{\mathrm{b}}$ & $100 \pm 0.02^{\mathrm{b}}$ \\
\hline Crypt Depth $(\mu \mathrm{m})$ & $18.0 \pm 0.01^{\mathrm{a}}$ & $33.0 \pm 0.01^{\mathrm{b}}$ & $35.0 \pm 0.01^{\mathrm{b}}$ \\
\hline Epithelial Height $(\mu \mathrm{m})$ & $17.0 \pm 0.01$ & $30.0 \pm 0.00$ & $34.0 \pm 0.00$ \\
\hline Lamina proprial Width $(\mu \mathrm{m})$ & $23.0 \pm 0.00^{\mathrm{a}}$ & $48.7 \pm 0.00^{\mathrm{b}}$ & $48.0 \pm 0.01^{\mathrm{b}}$ \\
\hline Submucosal width $(\mu \mathrm{m})$ & $55.0 \pm 0.01$ & $59.0 \pm 0.00$ & $77.0 \pm 0.01$ \\
\hline Muscularis mucosa width $(\mu \mathrm{m})$ & $223 \pm 0.02$ & $300 \pm 0.03$ & $301 \pm 0.02$ \\
\hline Lamina muscularis width ( $\mu \mathrm{m})$ & $55.0 \pm 0.01$ & $69.7 \pm 0.02$ & $62.3 \pm 0.00$ \\
\hline Serosal width $(\mu \mathrm{m})$ & $11.0 \pm 0.00$ & $11.0 \pm 0.00$ & $11.0 \pm 0.00$ \\
\hline
\end{tabular}

Means with different superscripts within rows are statistically significant $(\mathrm{P}<0.05)$

\section{Discussion}

This study shows that the crown- rump length, as well as the weight, width and length of the duodenum, jejunum and ileum, all increase with increase in age. This can be attributed to physical, physiological and anatomical adaptation to allow for change in diet in the animal. These are in conformity with the findings of Weaver and Carrick (1989), who observed changes in upper intestinal epithelial morphology and kinetics in the growing guinea pig. Findings from the study, especially with the adult African giant rat conform with those of Nzalak et al. (2015) who investigated the gross and histological features of small intestine of the adult African giant rat. As observed with the adult rats in the present study, Nzalak et al. (2015), had earlier reported that the jejunum is the longest portion of the small intestine of the African giant rat while the ileum is the shortest. It could be inferred that the digestive and absorptive roles of the small intestine in this rat is carried out more at the jejunum. The significant differences $(\mathrm{P}<0.05)$ observed between neonates and juveniles with respect to the height and width of the villi are suggestive of anatomical modifications to meet dietary demands. This is in conformity with the findings of Nwaogu and Ezeasor (2009), who worked on changes in the morphological features of the duodenum and jejunum of prenatal and postnatal West African Dwarf goats (Capra hircus).

The significant differences $(\mathrm{P}<0.05)$ observed in the villus height, villus width and crypt depth between the neonates and juveniles could be a measure of the neonates' adaptation to shifts from maternal milk to the consumption of solid and semisolid forages. Similar observation has been reported in six-weeks old pigs (Randal et al., 2001) and two to eight-weeks old lambs (Poole, 2001). This period of adaptation to change in diet is critical as significant and rapid changes in function and morphology of the gastro-intestinal tract (GIT) are known to be affected by certain growth factors (Klurfeld, 1997) such as epidermal and insulin- like growth factors (Pacha, 2000; Donovan et al., 2004) as well as secretions like bile, pancreatic juice, polyamines, GIT hormones, neural and genetic programming (Pacha, 2000).

Comparing villus height between the neonates and juveniles not only showed significant differences $(\mathrm{P}<0.05)$ but also revealed $188 \%, 228 \%$ and $30 \%$ increases for the duodenum, jejunum and ileum, respectively. This suggests larger surface area of the small intestine for digestion and absorption. These observations corroborate previous reports on villus height, crypt depth and cells per villus in pigs (VanGinneken et al., 2002; Mekbungwan et al., 2004), chicken (Moon and Skartvedt, 1975), guinea pigs (Weaver and Carrick, 1989), lambs (Poole, 2001) and rabbits (Gutierrez et al., 2002) during the first few weeks of post natal life. However, the observed increase in villus height with age is at variance with the report of Moon and Joel (1975), that the villi of new born lambs were longer than those of sheep at three weeks, three months and more than a year of age.

Numerous glands were present in the lamina propria of duodenum, jejunum and ileum as well as submucosa of the duodenum in the rats. These together with the presence of blood vessels indicate increased digestive and absorptive functions. The thickness of the tunica muscularis significantly increased $(\mathrm{P}<0.05)$ between the neonates and juveniles for the duodenum, jejunum and ileum suggestive of increased in muscular activity (peristalsis) in the rats. Nevertheless, this observation is at variance with the report that there was reduction in the thickness of tissue layers under the mucosa, especially tunica muscularis within the first 24 hours after birth in piglets (Randal et al., 2001). 
The significant difference $(\mathrm{P}<0.05)$ observed in the submucosa and submucosal widths of the neonates and juveniles are in conformity with previous report (Weaver and Carrick, 1989), on changes in mucosal morphology in rodents during the transition period between suckling and weaning. Gradual changes in mucosal morphology, functions and cytokinetics in the precocial guinea pig, accompany a relatively long and gradual weaning process. These changes could be brought about by dietary, hormonal and genetic factors (Yeh, 1976; Henning, 1987; Diamond, 1986). The mechanisms entailed in these had been related to changes in epithelial cell structure and function (Weaver and Carrick, 1989). These may involve either change in the epithelial cell population (Tsuboi et al., 1981) such as transcription or translation of enzyme activity (Henning, 1987; Koldovsky, 1972 and Koldovsky et al., 1983).

It can be concluded from this study that both the gross and histological parameters of the small intestine increase with a concomitant increase in the age of the animals. It has also shown that there is no significant difference between the intestinal morphology of juvenile and adult rats unlike those seen between neonate and juvenile rats. The outcome of this work, therefore, provides baseline data on the developmental morphology of the small intestine in the African giant rat (Cricetomys gambianus Waterhouse) and is expected to be useful in a better understanding of the structural modifications of the small intestine in an effort to achieve a more successful domestication of the animal.

\section{Acknowledgements}

The authors are appreciative of the support received from Mr Osuoya and the entire Technical Unit of the Department of Veterinary Anatomy, University of Ibadan, Nigeria; ably led by Mr A. W. Ramoni.

\section{References}

Ajayi SS. 1974. The biology and domestication of the African Giant Rat (Cricetomys gambianus Waterhouse). Ph.D Thesis, Department of Forest Resource Management, University of Ibadan.

Diamond JM. 1986. Hard-wired local triggering of intestinal enzyme expression. Nature 324: 408

Donovan SM, Hartke JL, Monaco MH, Wheeler MB. 2004. Insulin- like Growth factor1 and piglet intestinal development. Dairy Sci. 87: E47- E54.

Durotoye LA, Oke BO. 1990. A comparative study on the haemogram of the African giant rat (Cricetomys gambianus Waterhouse) and the Wistar rat. Trop. Vet. 8: 29-38.

Ellis H, Mulder C, Valverde E, Poling A, Edwards T. 2017. Reproducibility of African giant pouched rats detecting Mycobacterium tuberculosis. BMC Infectious Diseases 17: 298 DOI 10.1186/s12879-017-2347-3

Gutierrez I, Espinosa A, Garcia I, Sarabano R, Deblas JC. 2002. Effects of level of starch, fibre and lactose on digestion and growth performance of early weaned rabbits. J. Anim. Sc. 80: 1029- 2037.

Happlod RR. 1987. The Mammals of Nigeria. Clarendon Press Oxford, London.

Henning SJ. 1987. Functional development of the gastrointestinal tract. In: Johnson LR (ed) Physiology of the Gastrointestinal Tract. Raven Press, New York, 285-300.
Hugeholtz F, de Vos MM. 2018. Mouse models for human intestinal microbiota research: a critical evaluation. Mol. Life Sci. 149. https://doi.org/10.1007/s00018-017-2693-8

Klurfeld DM. 1997. Nutritional regulations of gastrointestinal growth. Frontiers in Biosc. 4: 1-7.

Koldovsky D, Palmieri M, Jumawan J. 1972. Inhibition of the cortisone-evoked increase of intestinal sucrase by actinomycin D. Proc. Soc. Exp. Biol. Med. 140: 1108-1110.

Koldovsky D. 1983. Role of intrinsic, hormonal and dietary factors in expression of perinatal development of mammalian small intestinal sucrose. J. Pediatr. Gastroenterol. Nutr. 2 (1): 145- 150.

Mekbungwan A, Yamauchi K, Sakaida T. 2004. Intestinal villus: histological alterations in piglets fed dietary charcoal powder including wood vinegar compound liquid. Anat Histol. Embryol. 33 (1): 11- 16.

Monadjem A, Taylor PJ, Denys C, Cotterill FP. 2015. Rodents of Sub-Saharan Africa: A Biogeographic and Taxonomic Synthesis. Walter de Gruyter GmbH, Berlin, Germany.

Moon HW, Joel DD. 1975. Epithelial cell migration in the small intestine of sheep and calves. Am. J. Vet. Res. 36: 213- 215.

Moon HW, Skartvedt SM. 1975. Effect of age on epithelial cell migration in the small intestine of chickens. Am. J. Vet. Res. 36: 213- 215.

Moutairou K, Hayez N, Poh L, Pathyn VG, Pochel R. 1996. Calbidin localization in African Giant Rat (Cricetomys gambianus Waterhouse). Biochemica et Biophysica Acta Mol. Cell Res. 13: 213-218.

Nwaogu IC, Ezeasor DN. 2009. Changes in morphological features of duodenum and jejunum of prenatal and postnatal West African Dwarf goats (Capra hircus). Trop. Vet. 27 (2): 1-10.

Nzalak, JO, Wanmi N, Imam JA, Umosen, AD. 2015. Anatomical and Histological Studies of the Small Intestine of the African Giant Rat (Cricetomys gambianus-Water house)- II. Ann of Expt. Biol. 3 (4):20-26.

Oke BO, Aire TA. 1996. The coagulating gland of the African giant rat (Cricetomys gambianus, Waterhouse). Trop. Vet. 14: 23- 29.

Oke BO, Aire TA, Adeyemo O, Heath E. 1988. On the accessory reproductive glands of the male African giant rat (Cricetomys gambianus, Waterhouse). Proceedings of the $11^{\text {th }}$ International Congress on Animal Reproduction and Artificial insemination. Dublin, Ireland.

Oke, BO, Aire TA, Adeyemo O, Heath E. 1989. The ultrastructure of the epididymis of the African giant rat (Cricetomys gambianus, Waterhouse). J Anat (Lond) 165: 75-89.

Olude MA, Mustapha OA, Olopade JO. 2017. Morphological Characterization of the African Giant Rat (Cricetomys gambianus, Waterhouse) Brain Across Age Groups: Gross Features of Cortices. Niger. J. Physiol. Sci. 31: 133-138.

Olukole SG. 2009. Morphometric analysis of the kidneys of the adult domesticated African greater cane rat (Thryonomys swinderianus) Eur. J. Anat. 13 (3): 117-120

Olukole SG, Oyeyemi MO, Oke BO. 2009. Biometrical observations on the testis and epididymis of the domesticated adult African Greater cane rat (Thyronomys swinderianus). Eur. J. Anat. 13 (2): 71-75.

Omirinde JO, Olukole SG, Oke BO. 2019. Age-related changes in the testicular and epididymal sperm parameters in the African greater cane rat (Thryonomys swinderianus, Temminck, 1827). Anim. Res. Inter. 16 (1): 3255 - 3264.

Pacha J. 2000. Development of intestinal transport function in mammals. Physiol. Rev. 80 (4): 1633-1667.

Poole CA. 2001. Ontogenesis of Peptide Transport and Morphological Changes in the ovine GIT. M.Sc. Thesis. Virginia Polytechnic Institute and State University, Blackburg, Virginia. 
Randal KB, Elnif J, Pucher-Gardiner AA, Sanglid PT. 2001. Intestinal apical amino acid absorption during development of the pig. Am. J. Physiol. Regul. Integ. Comp. Physiol. 280 (1): 241- 247.

Tsuboi KK, Kwong LK, Ford WDA, Colby T, Sunshine P. 1981. Delayed ontogenic development in the bypassed ileum of the infant rat. Gastroenterol. 80: 1550-1556.

Van den Bogert B, Leimena MM, De Vos WM, Zoetendal EG, Kleerebezem M. 2011. Functional intestinal metagenomics. In: De Bruin FJ (ed) Handbook of molecular microbial ecology, vol II: metagenomics in different habitats. WileyBlackwell, New York

Van-Ginneken C, Van-Meir F, Weyns A. 2002. Stereologic characteristics of pig small intestine during normal development. Dig. Dis. Sci. 47 (4): 868- 878.
Weaver LT. 1986. Milk and the neonatal gut: comparative lessons to be learnt. Equine Vet. J. 18: 427-429.

Weaver LT, Carrick BM. 1989. Changes in Upper Intestinal Epithelial Morphology and Kinetics in the Growing Guinea Pig. Paediatr. Res. 26 (1): 31-33.

Yeh KY. 1976. Cell kinetics in the small intestine of suckling rats. Anat Rec 188: 69-76.

Yeh KY, Holt PR. 1985. Rat milk maintains intestinal lactase activity in rat pups whereas artificial formulas do not. Pediatr. Res. 19: 963-967.

Yeh KY, Holt PR. 1986. Ontogenic timing mechanism initiates the expression of rat intestinal sucrase activity. Gastroenterol. 90: 520-526. 